\title{
Capitalizing on Opportunities during the Covid-19 Pandemic
}

\author{
Business Transitions among Chinese Immigrant Entrepreneurs in France
}

\section{抓住新冠疫情的机遇深化商业转型}

\section{以法国华裔企业家为例}

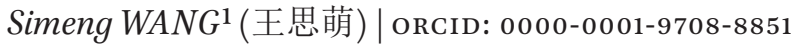 \\ The French National Centre for Scientific Research (CNRS), France \\ simeng.wang@cnrs.fr
}

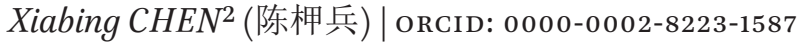

Sorbonne University, France

chenxiabing123@gmail.com

\begin{abstract}
This article analyses business transitions among Chinese immigrant entrepreneurs in France during the Covid-19 pandemic. Drawing on a historical overview of the development of ethnic Chinese businesses over the last century and an empirical study carried out in five different industrial sectors (import and export, retail, catering, hotel, and tobacco) of the French economy, we examine what challenges these entrepreneurs have faced during the pandemic, what strategies they have adopted in response to these challenges, and what has enabled them to shift business patterns and commercial practices in this unprecedented situation. Our findings show that the Covid-19 pandemic has accelerated the transition of Chinese immigrant entrepreneurship in France, from offline operations to digital business. However, the pandemic may not be the direct cause of this business transition; rather, it has created unique conditions which facilitate the transition. Before the pandemic, some Chinese entrepreneurs had
\end{abstract}

1 Wang Simeng, Ph.D., is a sociologist, Permanent Research Fellow at the French National Centre for Scientific Research (CNRS), France. She is also a fellow at the French Collaborative Institute on Migration (ICM).

2 Chen Xiabing is a Ph.D. candidate in sociology at Sorbonne University, France. 
already made or partially made the transition to "integrating online and offline businesses," "hiring beyond Chinese ethnic networks," and "paying attention to the local country's policy directions," which helped them greatly reduce the negative impacts of the pandemic. During the pandemic, two unprecedented business opportunities were opened up: "fostering local production" and "seeking low-risk sectors," which some Chinese entrepreneurs have proactively pursued since April/May 2020. These may be the new trends for Chinese entrepreneurs in France in the future. Theoretically, our study suggests that business transitions among Chinese entrepreneurs in France need to be examined beyond the framework of pure economic rationality, taking into consideration the intersection of new dynamics of Chinese migration into host country and the cross-cultural, cross-institutional, cross-thinking, and cross-border social engagement of the entrepreneurs themselves before, during, and after the pandemic.

\section{Keywords}

Chinese entrepreneurs - the Covid-19 pandemic - business transitions - France digital business

\section{摘要}

本文分析了新冠疫情期间在法华裔企业家的商业转型。通过对上个世纪华裔企业发 展的历史回顾, 以及在法国经济中的五个不同产业部门（进出口、零售、餐饮、酒 店和烟草) 进行的实证研究, 我们考察了这些企业家在疫情期间所面临的挑战, 他 们为应对挑战而采取的策略, 以及他们能在这些前所未有的挑战下成功转变商业模 式的原因。我们的研究结果表明, 新冠疫情加速了法国华裔移民企业家的商业转 型, 例如从线下经营转向数字化经营。然而, 疫情可能并非这些商业转型的直接原 因, 而是为转型创造了独特的条件, 促进了转型。在疫情发生之前, 一些华裔企业 家已经实现或部分实现了“线上线下业务融合”、“在华人族裔网络之外招工”、“关注 移入国本地政策导向”等商业转型, 这帮助他们大大降低了新冠疫情带来的负面影 响。疫情同时也为他们带来了两个前所未有的商机: “促进本地生产”和“寻求低风险 行业”。这是 2020 年 4-5 月以来一些华商的商业动向, 也可能是未来中国企业家在 法国发展的新趋势。在理论层面, 我们的研究表明, 考察在法华商的商业转型需要 跳出纯经济理性的分析框架, 去全盘分析华人移民与移入国的互动新动态, 以及华 裔企业家在新冠疫情前、中、后的跨文化、跨机构、跨思维、跨国界的社会参与。

\section{关键词}

华裔企业家 - 新冠疫情 - 企业转型 - 法国 - 电子商业 
This article takes Chinese entrepreneurs in France as an example through which to analyze the impact of the Covid-19 pandemic on business transitions. To begin, the authors review the history of the development of Chinese entrepreneurs in France and summarize Chinese business ecology in different social backgrounds over the past century and up until the Covid-19 pandemic. Thereafter, we present case studies on business transitions among Chinese entrepreneurs in France from five different industries (import and export, catering, hotel, supermarket and tobacco) during the pandemic crisis. For each industry, we explore the challenges they faced, the strategies they adopted and what enabled these entrepreneurs to make business transitions. Finally, in the concluding section, we summarize their strategies to combat these challenges, the key elements enabling these entrepreneurs to make changes, and the two unprecedented business opportunities which have emerged in the postpandemic era.

The material for this article comes from an empirical study combining qualitative and quantitative methods, carried out as part of the "MigraChiCovid" project. ${ }^{3}$ In terms of research methods, this article uses both first-hand and secondary qualitative data collected through three main research methods. First, we conducted semi-open interviews with 14 Chinese entrepreneurs in different industries: hotel, medical-related, import and export, catering, retail, and tobacco. Their businesses are mainly concentrated in Eastern Paris, especially the 4th, 10th, 13th and 2oth arrondissements, and in Aubervilliers, which is a northern suburb of Paris. Three of the interviewees either have served or are currently serving as presidents of associations in their industries or in entrepreneurial communities in their home country. They are all first-generation immigrants: several are skilled newcomers working in the catering and tobacco industries and others have children who are also involved in the management of their businesses. Secondly, in order to fully understand their professional activities and work environments, we conducted participatory observations in their workplaces. Thirdly and finally, we monitored media in three languages (Chinese, French and English) on topics related to Chinese entrepreneurs in France facing the Covid-19 pandemic.

3 This research project (France, ANR-20-COVI-0046-o1) aims to study the social views, feelings, attitudes and behaviors of Chinese people and their descendants facing the Covid-19 pandemic in France. For more details, please refer to: https://www.migrations-asiatiques-en -france.cnrs.fr/projet-migrachiCovid/resume-scientifique-du-projet-migrachiCovid. 
The large body of literature addressing immigrant entrepreneurial identities and their entrepreneurial trajectories (Nazarene, Zhou, \& You 2019) since 2000 provides the theoretical basis for this paper. Although these reviews are mainly based on cases in the United States and other English-speaking societies, comparing these studies with Chinese entrepreneurs in France helps us identify the differences and commonalities in the identity attributes and entrepreneurial characteristics of immigrant entrepreneurial groups.

The history of the first large-scale Chinese arrival in France can be traced back to the First World War when more than 140,00o laborers from China came to the European continent. After the war, about 5,000 to 7,00o people stayed in France (Condliffe 1928). During the same period, workers and artisans from Qingtian, Zhejiang, arrived in France by way of Eastern Europe. They gathered near the Lyon train station in the 12th arrondissement of Paris, mainly selling handmade goods (Live 1992). At the time, Chinese business people had limited interactions with the host society because of language, type of work and living conditions. Similarly to early immigrants in America, they "were not connected to the social structures of the communities where their businesses were located" (Min 1996). During the "glorious years" around the 1930s, a number of Chinese restaurants emerged on the left bank of the Seine in Paris. Since the 1960s, Chinese business people have established Chinese-style furniture and supplies maintenance, import and export, and retail businesses in the 11th and 12th arrondissements of Paris.

In the late 1970s and early 1980s, there was another significant wave of Chinese migration to France, which consisted mainly of members of the Chinese diaspora who left Southeast Asia due to political factors and wars. These immigrants have a particular identity because their Chinese ancestors lived in Southeast Asia for several generations yet maintained their Chinese identity throughout generations of living overseas (Wang 2007). In France, these immigrants established themselves in the 13th arrondissement of Paris (Hassoun and Tan 1986). The businesses frequented daily by the Southeast Asian Chinese community - such as supermarkets, restaurants, food and porcelain wholesalers, cheaper hairdressers and insurance companies - formed

4 This paper was presented at the UCLA International Symposium on Global Chinese Entrepreneurship, 20-21 November 2020 . A previous version of this article was published in Chinese in The International Journal of Diasporic Chinese Studies (华人研究国际学报), $\mathrm{n}^{\circ} 12$. p. 1-23. The authors have obtained the translation and editing rights from the journal. This article is part of the results of the MigraChiCovid research project, funded by the French National Research Agency (France, ANR-2O-COVI-oo46-o1). 
a closely-coordinated intra-ethnic business. These entrepreneurial structures also provided employment opportunities within the ethnic group. Chinese business people began to integrate into the local market as well, operating garment factories at cheap cost and providing sources for local wholesale clothing in France.

At the same time, businesses operated by Wenzhou entrepreneurs were also booming, from smaller-scale family workshops, notably the "three knives" (cooking, hairdressing and tailoring) to a large-scale import and export trade industry including international production and sales chains connecting China and France. The four major Chinese districts in Paris in the 1980s included the 13th arrondissement, the 19th arrondissement from Belleville to Crimée, the 18th arrondissement near the border of the 19th, and the 3 rd arrondissement around Arts-et-Métiers (Hassoun and Tan 1986). We also need to point out that the immigration trajectories and experiences of French-Chinese business people are more or less similar to their compatriots in other European countries. During the Chinese economic reform and opening up in the late 1970s, Chinese people saw Europe as a chessboard for finding opportunities (Ceccagno 2003). Consequently, a large number of less educated and less skilled Chinese immigrants quickly became wealthy in Western and developed countries.

Although there were huge differences between the Chinese immigrants living in these different neighborhoods, their common language or family and ethnic relations helped create links between them. Through this network, the Chinese community was able to build an impressive pre-information age knowledge base. At this time, Chinese business people began to develop the characteristics of an "enclave economy" (Zhou 2004). In terms of financing channels, Wenzhou and Chaozhou people used "Qi Hui" to raise funds in the early stages of business, and had specific relationships within the ethnic group. Small investment gatherings were held in the group. Similar to situations which we might find in Los Angeles or Singapore, this system allows Chinese in foreign countries and lacking bank loans to do business in non-mainstream society by relying on trust and reputation (Long 1998). Wenzhou business people in France, extensively studied by Wang Chungang (2017), have experienced generational changes, and their business philosophy, strategy and attitude are constantly being updated and adjusted. From this, we can find that,

5 This is a way to raise funds and to hold small investment gatherings through communitybased relationship circles, usually within clan or kinship circles. In the absence of bank loans in a foreign country, this is a basic way for Chinese people to do business in France, relying on trust. It is similar to what is called "Piaohui" in Singapore or "Yuelanhui" in certain regions of Mainland China (Wang C. 2017). 
as observed in American society, Chinese business people as a whole continue to develop in the direction of the urban middle class. The theoretical analysis based on the "middleman" and "enclave economy" (Light 1994) is no longer sufficient to describe the subsequent development of Chinese business in France.

From the 1990s to the beginning of the 21st century, a new Chinese immigration flow emerged. These immigrants were actively engaged in commodity export and established small businesses. Unlike previous immigrants, they often arrived in France with the funds necessary for their establishment and actively participated in China's distribution chain as a "world factory" (Ma Mung 2009). In the 199os, more and more Chinese business people of Zhejiang and Guangdong origins began to establish entrepreneurial associations. These associations have integrated the capabilities of Chinese business clusters and played an important role in the international trade production and sales chain (Li 2002).

In 2001, China joined the World Trade Organization, which provided more possibilities for overseas-Chinese business people to purchase goods from China, and allowed Chinese entrepreneurship to become more global than ever before. Transnationalism has become an important feature of international entrepreneurship, whether through individual immigration, the diaspora community of the host country or even multilateral government organizations. It can also be seen in the many interconnected networks created by ethnic groups and their associations, which most businesses belong to (Levitt and Glick-Schiller 2004; Portes et al. 2002; Portes and Fernandez-Kelly 2015). With the progress of globalization, Italian-Chinese business people have gradually begun to participate in various economic activities in the international industrial division of labor, such as manufacturing (Ceccagno 2015). There are some similarities between France and other European countries in the organizational forms and ethnic relations of Chinese entrepreneurs. These entrepreneurs all attach great importance to family and ethnic relations, and the trend of industrial upgrading is also very similar. For example, as Guercini and her colleagues have pointed out regarding the future trend of the Prato Chinese Immigration Company, there has been a gradual diversification in activities, from traditional clothing manufacturing to investing in other new businesses (Guercini, Milanesi \& Ottati 2017).

By the turn of the millennium, hundreds of Chinese import wholesalers had gathered in the 3 rd and nth arrondissements of Paris. They wholesaled goods such as jewelry, leather bags, children's clothing and ready-to-wear clothing, with nearly 700 wholesale stores on the three main streets in the residential area of the 11th arrondissement. This phenomenon of rapid development was 
mainly due to the "getting together" mentality that is quickly built up by family or acquaintance networks within an ethnic group, and characterized by a high self-employment rate (Spener and Bean, 1999). In 2003, local citizens in the 11th arrondissement began to complain to the government about the single business model of Chinese business people; as a result of this model, other businesses, such as restaurants and supermarkets, could no longer easily enter the market. At the same time, the municipal government of Aubervilliers, which had large-scale storage capacities, opened its doors to Chinese business people. Drawn to the ample space, lax policies, and convenient logistics and transportation, the Chinese business people who were originally located in the city center gradually relocated to Aubervilliers. According to local government statistics, there are currently more than 1,0oo Chinese-operated wholesale stores (Trémon 2012).

Since 2010, with the rapid increase in the number of students coming to France and the growth of other high-skilled immigrant groups, Chinese immigration to France has ushered in a new wave in history (Wang 2020) that makes the profiles and occupations of the Chinese in France increasingly diverse. Their places of residence and employment also extend beyond some of the Chinese neighborhoods mentioned above. After graduation, some international students choose to enter the local labor market, while others start their own businesses. This new generation of entrepreneurs with high academic qualifications is different from the Wenzhou and Southeast Asian business people who devoted themselves to traditional businesses. In the early stages of this high-skilled immigrant group's entrepreneurship, they have focused on emerging industries such as the Internet and done their best to integrate the electronic business model with traditional industries, such as developing electronic platforms for ordering and delivery, developing programs for purchasing discounted goods online, contributing to the bespoke tour service industry (Li 2019), purchasing luxury goods or maternal and child supplies for domestic consumers (Wang S. 2017), and opening Chinese schools and parent-child classrooms, among others. At the same time, they have mostly abandoned the saturated inward-looking ethnic economic industry and instead target French local markets and even global customers.

Given its republican model of integration, in France there is no Chinatown similar to those found in the United Kingdom and the United States. Compared with Chinese business people in the United States, the attributes of the "enclave economy" in France have always been relatively weak. However, over the past century Chinese entrepreneurship in France has come to share some similar overall trends with the US model, such as: 
- Retail and service industries are notable industries for Chinese business people, and are now more diverse in type and scale. For example, restaurants have evolved from simple and small to diverse and luxurious.

- Chinese enterprises are now integrated into the local economy, with many trying to "break through" ethnic boundaries and spread to middle-class cities and suburban communities.

- Industries that historically seemed out of reach to immigrant entrepreneurs have appeared in large numbers in the primary market sectors of the rapidly globalizing mainstream economy. Capital-intensive and knowledgeintensive industries are typical examples.

It should be pointed out that before the Covid-19 pandemic, some Chinese entrepreneurs, notably skilled ones, had already made or partially made the business transitions to "click-and-mortar businesses," "hiring beyond Chinese ethnic networks" and "paying attention to the local country's policy directions." These transitions helped significantly to reduce the negative impact of the pandemic. In the following section, we analyze business transitions during the Covid-19 pandemic among Chinese entrepreneurs in France across five industries including the challenges, the strategies and the keys to success.

Chinese Business Transitions during the Covid-19 Pandemic: Challenges, Strategies, and Keys to Success

From the end of February to mid-March before the French government issued the "lockdown" order, many Chinese business people in France had already slowed down their economic activities due to the first outbreak in China. After this order in mid-March, Chinese-run traditional wholesale and retail businesses and catering services were almost completely suspended. Very few could continue to work during the lockdown period. After the end of the lockdown in mid-May, many companies with factories in China were affected by factors such as the shrinking market and a reduction in flights, and their businesses became stagnant.

The Covid-19 pandemic has posed unprecedented challenges to business people, but has also provided an opportunity for them to innovate and change. Our empirical research and findings show that the Covid-19 pandemic may not be the direct cause of business transitions, but rather creates unique conditions which facilitate the transition. It has stimulated and catalyzed business transitions in the Chinese diaspora in France. Below we analyze typical cases in five different industries. 

Catalyzed by the Pandemic

2.1.1

Historical Changes in the Industry under Normal Circumstances

before the Covid-19 Pandemic, and Recent Challenges during the Pandemic Crisis

Since the lifting of the ban in France on 11 May, the merchants in the Chinese Import and Export Wholesale City in Aubervilliers, a northern suburb of Paris, have generally resumed operations. The target customer base is very diverse, including merchandisers from not only Paris and neighboring French provinces, but also other European countries. The Chinese Import and Export Wholesale City in Aubervilliers has a certain number of "enclave economy" characteristics. Along with over 1,500 Chinese-owned stores, there are many Chinese business associations with clear community guidelines.

The optical shop operated by Mr Xia, whom we interviewed at the end of July, is located in Aubervilliers. Compared with the ready-to-wear clothing, groceries, accessories, luggage, etc. that other Chinese business people sell, the glasses sold by Mr Xia are relatively high-tech products. In his words, "the barriers to entry are relatively high, and technology and products are not easily copied. There is depth and breadth." Mr Xia, who was born in Wenzhou, came to France in 1987 and founded this import and export company in 1992. It currently has 18 employees and although it is now run by his daughter, Mr Xia still goes to the shop every day and plays a significant advisory role.

Mr Xia commented on the historical changes in the import and export wholesale industry: "From 20oo, when China had just joined the wTo, no matter who came here [to the Chinese import and export wholesale business circle in Aubervilliers], there was a shop that had what they were looking for. It was so easy to do business"; "it can be said that the period from 2000 to 2020 was the most glorious time for overseas Chinese to do business abroad"; "I feel that from 2010 to the present, over the past 10 years, stores have gone out of business more, and fewer have come in." These scenarios describe a trend change in the traditional import and export industries in this region during the process of globalization. At the beginning, these industries had extremely high enclave economic attributes and the self-employment rate of enterprises was very high. In this early stage they were all beneficiaries, but as the cluster effect reached its highest value, internal competition appeared in the traditional import and export market. This prompted entrepreneurs like Mr Xia to choose higher value-added industries and provide professional services.

Although Mr Xia is still in the field of import and export, he is not optimistic about the future of this sector, which has been, according to him, very 
much weakened by the Covid-19 pandemic. He said that "the overall situation of the wholesale business circle continues to decline, but it has not yet reached the bottom. This [wholesale] business district market has shrunk and expanded. It is now 1,500 businesses, and it may become 1,000 or even 500 in the future." This situation also threatens Mr Xia's own business; what is the solution here?

\subsubsection{What Strategies Have Been Employed in Response to These Challenges?}

2.1.2.1 Acquisition of Local Companies, Reduction of the Self-Employment Rate, and Further Promotion of the Integration of the Ethnic Economy into Mainstream Society

"Now we can acquire some local companies, because the price of assets has been reduced. Chinese people can actually do this now; it is an opportunity. I am also thinking about whether to set up a factory that produces glasses here." The objective of this strategy is to combine one's own capital strength with the production capacity of the local society, and encourage second-generation immigrants to participate in the management of enterprises so that such high value and professional service businesses are truly based in French society.

\subsubsection{Deepen the Global Strategy}

The pandemic has impacted globalization, but globalization could still be an optimal solution for realizing capital and industrial integration. To solve the problems caused by globalization is more to reform the strategy of corporate globalization. For example, Mr Xia mentioned that "each enterprise needs to have a brand and a sales network. Even if one buys a local business, one has to package and transform it into an international company." For his business, he hopes to find suppliers outside China, in Vietnam or India. In France, descendants of Chinese business people like Mr Xia's daughter are actively developing China's high-end consumer market, trying to create "Made in France" brands and products, and then selling them to China (Wang 2019). As French-born Chinese children who grow up in a Chinese entrepreneurial cultural environment are at the same time being educated and learning skills in France, they are uniquely equipped to play an intermediary role in the transnational trade linking the home country of their parents (China) and their own country (France). This is echoed in the research results from studies carried out in other European countries (Thunø and Li 2020). With a multilingual and multicultural educational background, these second-generation Chinese immigrants have more opportunities to manage transnational markets between China and Hungary (Nyiri 2014). Similarly, because they are better integrated into local society and well educated, descendants of Chinese migrants in Portugal have 
sufficient skills to consider finance or other services such as platform economies when choosing a career, instead of simply working in their parents' industries (Gaspar 2019).

\subsubsection{What Enables Businesses to Shift Business Patterns and Commercial Practices?}

In Mr Xia's case, to adopt this new strategy he and his daughter not only need to investigate the local market more deeply and integrate into the mainstream French economy but also need to pay attention to issues such as the productivity level of different production areas in the world and the purchasing-power level of different markets. Chinese business people have a natural advantage in understanding China's relevant international trade policies and actual levels, and also have the opportunity to use the next international trade cooperation (such as RCEP, China-EU negotiations on investment etc.) to achieve their own industrial upgrades. Mr Xia would need to use his perspective as a vantage point from which to spy on the dynamics of the entire industry, as well as increase his understanding of the relevant markets in France and in China.

Thanks to the fact that the products traded by Mr Xia are high-tech, and that his daughter who has taken over the business is skilled and trilingual (in French, Chinese and English), the Xia family business can continuously interact with its network and country in a transnational society, while taking part in the socio-economic and political environment of both the home country and the host country. In this sense, by achieving "simultaneous embeddedness" (You and Zhou 2019), the Xia family business can resist the negative impacts of the Covid-19 pandemic.

\section{2 \\ The Catering Industry: The General Trend of Online Operations Catalyzed by the Covid-19 Pandemic}

2.2 .1

Historical Changes in the Industry under Normal Circumstances

before the Covid-19 Pandemic, and Recent Challenges during the

Pandemic Crisis

Because the Chinese in Paris came to France in large numbers and groups, their migratory trajectories were inherently heterogeneous. For a long time, the Southeast Asian Chinese restaurant owners in the 13th arrondissement mainly served their own compatriots. The Wenzhou Chinese business people in the 3 rd arrondissement, being themselves economic immigrants (Hassoun and Tan 1986), often catered to relatively poor immigrant communities in the early days. More recently, with the increase in new and high-skilled immigrants as well as the second generation of Chinese immigrants who have grown up in France, restaurant owners are overall better educated, and their understanding of the catering industry and ambitions for the market have changed. 
The complexity of the catering industry is largely manifested in the close integration of upstream and downstream segments. From raw materials to finished products to sales, there are higher fresh-keeping requirements than in other industries. With globalization and the Chinese entrepreneur's expansion into the local market, this industry form has gradually seen the integration of other ethnic groups. The Covid-19 pandemic has accelerated such integration.

In the past, family-style and small workshop-style Chinese restaurants gradually merged into a link in the food-industry chain. No matter what kind of restaurant it is, it can find suitable suppliers in the food market in time, thanks to a tradition of intra-ethnic cooperation that reflects the progressiveness of Chinese business people. As Mr Xue, the owner of a well-known Chinese restaurant in Paris, said: "I am from Shandong. Most of my suppliers are overseas Chinese in Southeast Asia, and I also do [business] with many Wenzhou business people." The catering industry is more transnational than ever before.

However, at the beginning of the outbreak in France, many food retailers rushed to buy ingredients, which caused short-term tensions for wholesalers and shocks that were felt along the entire supply chain. "With rice, for example, the prices in the Chinese supermarkets have all increased, and my suppliers are all in the Chinese supermarkets, so the price rose by more than ten yuan in those two days, and water spinach rose from 12 to 18 yuan." Nevertheless, thanks to the food industry chain of globalization, the soaring prices caused by this short-term concentrated rush were quickly alleviated, and the air transportation of special ingredients also returned to normal much earlier than did the flow of people, thus allowing the Chinese catering industry as a whole to avoid a shortage of raw materials.

Moreover, as the catering industry has developed it has gradually diversified from the previous low-end market, ranging from Michelin-starred to ordinary restaurants, and one Chinese owner might have multiple restaurants catering to different customer groups. Additionally, young high-skilled immigrants have created a network platform for ordering food in France. If this is an example of the integration of the catering industry into the global industry chain, it is also an example of business cooperation between overseas Chinese from different regions and backgrounds. Driven by the wave of digitization in businesses over the past decade, the Chinese catering industry in France and upstream and downstream companies have gradually realized different formats of business with online platforms. China has nearly two decades of experience in online platform construction, and the food delivery industry has also developed indepth for nearly ten years. For quite a long time, Chinese business people in Paris were relatively inexperienced in this online field. A group of young skilled migrants spotted this market for ordering food online, and established 
the platform "Alorsfaim" in 2017, which directly promoted physical restaurants of all sizes to Chinese and overseas Chinese through digital marketing. It touches the entire supply chain: supply, restaurant launches, and delivery of final products.

The Covid-19 pandemic is undoubtedly the catalyst for this digital trend and popularized the platform "Alorsfaim" with many other restaurant owners. Manager of "Alorsfaim" Mr Li told us: "Before the pandemic, our daily order volume was about 100 orders. Now, this has probably increased by five or six times." Because online platforms have a large amount of industry data and provide a reliable information foundation for in-depth cooperation in the postpandemic era, $\mathrm{Mr} \mathrm{Li}$ is convinced that this online platform could successfully enter the local French market, introducing more authentic Chinese food to French customers and going beyond national and cultural boundaries.

\subsubsection{Strategies in Response to Challenges \\ 2.2.2.1 Cooperating with Online Platform and Logistics Companies}

Before the pandemic, the cross-format cooperation between restaurants and online sales platforms was weak; this can be attributed to the relatively high service cost of the platforms and the fact that French customers generally prefer enjoying food in physical restaurants. However, this collaboration has improved during the pandemic. Although there are still service costs for these intermediary platforms, they have expanded the French market's understanding of Chinese food, beyond Chinese ethnic boundaries.

As a high-skilled migrant, Ms L is the owner of a Chinese tea shop. She opened it in the 200os, a moment when, in her words, "new opportunities were possible for Chinese business owners.... China had just entered the World Trade Organization, which changed how Chinese culture was perceived in France and gave us more legitimacy in certain fields." She spent a lot of time traveling to major tea-producing regions in China. In the context of the active development of transnational commercial cooperation, she selected the most suitable high-quality tea for the French market and entered the French mid-tohigh-end tea market. Its business scope has extended beyond Paris and France, now covering all of Europe. She has also established partnerships with French luxury-goods companies. During the pandemic, online sales have become an important part of maintaining her business. She was actively engaged in online sales before the arrival of the Covid-19 pandemic and her sales channels were diverse. She also worked with the French post office, so that her goods could be delivered to customers' homes smoothly even under the conditions of the lockdown. 


\subsubsection{Playing the "Good for Your Health" Card}

Ms L markets tea as a beneficial product for overall health. During the pandemic, she experienced an unexpected surge in sales. Ms L said: "Many of our customers come to the store and say that they can't drink one liter of wine or coffee when they are locked down at home, but they drink a lot of tea.... Most of the people who buy my tea are health-conscious. Many customers say they have to buy more of our tea."

\subsubsection{Maintaining a Solid Partnership with Chinese Providers in China} The trusting relationship and friendship established by Ms L with Chinese tea farmers and merchants played a key role in managing exceptionally challenging international logistics during the pandemic. She recalled: "Although it was difficult this year, our solid partnership with Chinese tea farmers allowed me to receive the new spring-tea supply of this year, in May. I was very worried that I wouldn't get fresh tea from this year because of Covid-19." Of course, in addition to this well-founded and well-maintained partnership with tea farmers, this successful supply is also due to the fact that in China the pandemic was brought under control in April and May, and tea farmers were able to work and send sufficient supplies abroad.

\subsubsection{What Enables Businesses to Overcome the Challenges of the Covid-19 Pandemic?}

We can conclude that under normal circumstances, before the Covid-19 pandemic, the Chinese catering industry in France was already undergoing a business transition, seen particularly in the efficient combination of online platforms and traditional modes of operation. The pandemic has accelerated this business transition. As an emigration country, China has a wealth of experience in areas such as network platform operations. All of these technologies and digital supplies have allowed Chinese business people as immigrant entrepreneurs to experiment with digital business in the catering sector in France.

Moreover, Chinese entrepreneurs in catering have gradually expanded their customer base and developed a wider market, targeting not only Chinese customers but also non-Chinese Europeans. This second business pattern shift has enabled these entrepreneurs to mitigate the loss of turnover linked to onsite consumption during the pandemic.

Finally, the deeply rooted transnational links between these entrepreneurs and Chinese producers in China have ensured a steady supply and commercial chain even during the Covid-19 pandemic. 


\subsection{Chinese Supermarkets: Different Sizes, Different Challenges and Strategies}

2.3.1 Historical Changes in the Industry under Normal Circumstances before the Covid-19 Pandemic

Like the catering industry or the import and export industry, the Chinese supermarket has maintained its status as a "middleman" from the beginning. Today, there are still many smaller Chinese supermarkets which target localcommunity customers, such as Chen Market. Others have gradually developed into medium-sized stores, such as 37 Express, and even large supermarket chains, such as the Paris Store, which has more than 22 branches in major cities across the country and more than 700 employees. These supermarkets can coexist without a fiercely competitive relationship, because the customer groups they target are different. Besides their local Chinese customers, many Chinese supermarkets also have a considerable proportion of local French customers. In other words, they have become integrated into local society.

2.3.2 Recent Challenges during the Pandemic Crisis and Corresponding Strategies and Solutions

Based on the size of supermarket, the three supermarkets we studied face different challenges posed by Covid-19. Accordingly, owners have adopted various corresponding solutions and strategies.

- For small supermarkets such as Chen Market, the owner told the authors that after failing to apply for emergency business financial support from the French government, the company decided to reopen on April 12. Mr Chen said: "Many of our customers are elderly people living in the district. They don't know how to use online shopping tools, but their daily needs must be met. With this health emergency, keeping our store open is our responsibility." One week after reopening, Mr Chen said: "7o percent of the employees are willing to return to work, mostly men. That is thanks to a good relationship maintained with my employees."

- A medium-sized supermarket like 37 Express faced decreasing numbers of customers at the beginning of the lockdown. Two weeks after the lockdown, the company chose to provide an online mail order service. It took a week to digitize the entire shopping process. As of 8 April, customers can shop at home through mobile phones and computers and receive home delivery via the French postal service.

- For large Chinese supermarkets such as Paris Store, most of the company's stores have continued to operate during the pandemic while limiting the 
number of customers in the store according to French Ministry of Health regulations. All employees are equipped with masks and protective gloves. In order to resolve the supply problem, the company chose a local supplier. In addition, the company has opened an online ordering service, where consumers can go to the store to pick up goods.

\subsubsection{What Enables Businesses to Overcome the Challenges of the} Covid-19 Pandemic?

Chinese supermarkets are generally small public spaces, where sellers and consumers, most of whom are Chinese, are connected through hometown products. The Covid-19 pandemic revealed the essence of this small publicspace relationship. When employers request that employees return to work, consult with them, and are willing to negotiate, employees are mostly compliant. During the Covid-19 pandemic, a high self-employment rate contributed to a mutually trusting relationship between employees and employers. When employees feel that hygiene and personal protection conditions are prioritized, they go back to work with confidence.

Secondly, the diversity and increasingly broad access to goods and items in these Chinese supermarkets is worth mentioning. With supplies not only imported from other Asian countries but also supplied locally, supermarkets have been able to buffer the negative effects of the pandemic.

Finally, online order and delivery services are also a central part of the Chinese supermarkets' business transitions, which has mitigated the loss of customers during the pandemic.

\subsection{Chinese Hotel Chains: Continuing to Operate during the Lockdown and Mobilizing Employees to Participate in the Fight against the Pandemic in France}

2.4.1 Historical Changes in the Industry under Normal Circumstances before the Covid-19 Pandemic and Recent Challenges during the Pandemic Crisis

The case study of this sector must be presented from the outset as unique and exceptional, because it is rare for a Chinese businessman, as an immigrant, to hold a position in the mainstream hotel market in a host country.

$\mathrm{Mr}$ Wu graduated from Xi'an Jiaotong University. He arrived in France to do a Ph.D. in 1983 and received his doctorate four years later. In 1993, he decided to start a business. After more than 20 years of operation, $\mathrm{Mr} \mathrm{Wu}$ is the CEO of the French Hipotel Hotel. He has operated 15 budget hotel chains in Paris, employs 150 employees, and has more than 800 suites that can accommodate 2,ooo people. Having started his business in France on the eve of globalization, 
Mr Wu's entrepreneurial identity differs from the "middleman" or "enclave economy" of the previous era. Instead, he is more likely to draw on his own capital and knowledge to start a business.

In MrWu's company, there is a lower self-employment rate than in the other Chinese business groups studied here. It is precisely because of the lower selfemployment rate that he has the ability to continue operating his business despite the impact of the Covid-19 pandemic. We will return to this point later.

With China's reform and opening up and the continuous development of the tourism economy as well as the continued liberalization of Sino-French visa policies, globalization has provided $\mathrm{Mr}$ Wu not only with relatively low operating costs, but also with a steady stream of tourists. However, the Covid19 pandemic has brought this kind of international travel flow to an abrupt halt. Mr Wu must consider replenishing his lost customers by other means, particularly developing the local market in France.

\subsubsection{What Strategies Are Employed in Response to These Challenges? \\ 2.4.2.1 Exploring the Local Market and Participating in the Fight against the Pandemic in France}

Mr Wu said: "After Macron announced the lockdown, all the French people 'disappeared' in one day, and everyone stayed at home. For a while, I didn't know whether the hotel would reopen or not. Because we can choose whether to close our doors.... Ten of them continued to operate, and the other five closed as soon as they had no business. So why did we reopen? We responded to President Macron's appeal. We received medical staff, police, state civil servants, and some social-relief organizations as well as homeless families who were at risk of contracting the virus. Also, during the lockdown period domestic violence in France increased by 36 percent, and some victims have been accommodated temporarily in our hotels. I feel that my hotel chains have made some contributions to France's fight against the pandemic. If we close our doors, where will all the health-staff members, policemen and victims of family violence stay?"

\subsubsection{What Enables This Business to Overcome the Challenges of the Covid-19 Pandemic?}

From his description, we have learned two key elements to success. Firstly, in the absence of international travel flows, $\mathrm{Mr}$ Wu made a strategic decision to turn to the development of the local market, finding new and special customers during the Covid-19 pandemic. This has alleviated the temporary loss of guests.

Secondly, the low self-employment rate played a crucial role and enabled the hotel chains to remain open during the lockdown: "They [the Chinese 
employees] are more affected by what happened in China, their home country; all of them chose to stay at home to protect themselves and their loved ones. They were reluctant to keep working in March, April and even July. I can understand that. Fortunately, in my hotels, most of the employees are from other ethnic groups or local French! They kept working during the lockdown." Indeed, the employees of non-Chinese origin that $\mathrm{Mr} \mathrm{Wu}$ hires are less "fearful" of the Covid-19 pandemic and this low self-employment rate has allowed the business to maintain normal activity during the pandemic.

All the above four industries have been deeply affected by globalization, and the Chinese entrepreneurs that we interviewed are tightly linked both to China, their country of origin, and to France, their host society. In our analysis, we mainly applied the theoretical perspective of "simultaneous embeddedness." However, some Chinese-held industries have not been as deeply affected by transnational flux as the above four industries. The industry we are going to discuss below plays an important role in local residential communities. Because of its special status and stability, this profession has withstood the test of the pandemic and continues to attract potential Chinese business partners.

\subsection{During the Epidemic, Tobacco Shops - A High Threshold and Low Risk Sector - Demonstrate Advantages}

This type of enterprise - high-threshold and low-risk tobacco retail stores has suffered relatively little from the impact of the Covid-19 pandemic.

$2 \cdot 5 \cdot 1$

Historical Changes in the Industry under Normal Circumstances before the Covid-19 Pandemic

In France, the sale of various types of tobacco is a national patent. Due to a state monopoly, these businesses can only operate after obtaining local-government bids by individuals or alliance enterprises. There are currently 24,0oo tobacco shops in France. To become a tobacco shop operator, you must have French nationality or the nationality of an EU member state, provide a non-criminal certificate, and prove that you do not hold shares or management rights in other tobacco shops (one person can only own one tobacco shop), along with other strict procedures. In 2013, the annual report of the Federation of Tobacco Shops in the Île-de-France region showed that nearly 45 percent of tobacco shop owners in the area were members of the Asian diaspora. ${ }^{6}$

6 Le Parisien. 2014. "La moitié des bars-tabacs gérée par la Communauté asiatique." (The Parisian Newspaper "Half of the Tobacco-Bars Managed by the Asian Community"). https://www.leparisien.fr/paris-75/la-moitie-des-bars-tabacs-geree-par-la-communaute -asiatique-o8-02-2014-3570567.php. Accessed on 15 October 2020. 
Under strict market control, local governments hardly ever issue licenses, and investors who intend to enter the market can only purchase existing stores. The tobacco shop, important in French culture, has continuously expanded its business scope and has become a meeting point for a wide variety of products and a constant stream of customers. Their relatively fixed profit is mainly tobacco commissions or various handling fees drawn from the state: an easy category to operate or to obtain income from. In this way, operators only need to subscribe to enough tobacco stamps from the state and sell to regular customers, even if their work intensity is significant. After acquisition, they must undergo short-term on-the-job training to fully understand the operation and rules of the entire industry. Tobacco shops in the French capital and major cities are generally open 12 hours a day, six days a week.

Many tobacco shops run by the older generation of Chinese immigrants gain profits through hard work and invest them in the education of their children, as well as achieving social integration and experiencing a rise in social class. For example, a tobacco shop owner from Aubervilliers told us: "At the time, my main consideration was our young child, and this business was relatively stable. If I work in other enterprises, I am afraid that I will lose money, and I will not be able to send my children to good schools. Now, two of my three daughters are in foreign companies, they do not want to do our jobs."

On the other hand, the new generation of Chinese immigrants who have obtained higher education is also willing to invest in this industry. Weiwen, originally from Hangzhou, got married and had children after studying in France, and bought a tobacco lottery shop in the western suburbs of Paris in 2002.

\subsubsection{An Industry Very Little Impacted by the Covid-19 Pandemic}

During the epidemic, tobacco stores were among the few businesses allowed to continue operating. The day after the lockdown, Weiwen opened the store as usual. There were fewer customers, but business did not decrease. In order to reduce the chance of infection, Weiwen changed the business hours from eight to four hours a day, five days a week.

Another tobacco shop owner, Mr Huang, is from Wenzhou and speaks fluent French. In 2004, his family sold a restaurant in the center of Paris and he decided to buy a tobacco shop as an experiment. After the lockdown measures were implemented, Mr Huang continued to operate for three days. Then, for health considerations, his parents repeatedly urged him to close the store for three weeks. It was not until early April that Mr Huang reopened his doors. He said: "When we first opened, we were only open for four/five hours, and then only gradually increased. It was not until 17 May that we resumed normal 
business hours. It is clear that the pandemic has not diminished the demand for smoking." Mr Huang added, "The residents are mostly of retirement age and our guests wear masks to buy cigarettes and leave quickly afterwards; their concern can be felt in the tone of their voice." According to him, compared to before Covid-19, the turnover during the lockdown has decreased by at least 30 percent, but he hasn't lost money.

\subsubsection{An Emerging Favored Industry?}

As far as the industry is concerned, the prices for selling tobacco and lottery tickets are completely regulated by the government, so profits are extremely weak and strictly controlled. During the Covid-19 pandemic, this industry has experienced fewer risks, and comparatively little investment and stockpiling, which makes it relatively stable. Mr Huang said: "If you compare us with other nearby businesses, I am still lucky. In France, any coffee and tobacco shop represents the vitality of the city and the neighborhood and the affinity of the residents. It's one way to have contact with the outside world." Identified as a "stable industry," the tobacco industry is therefore increasingly favored for investment by the Chinese business people we interviewed.

\section{3}

\section{Conclusion}

After a century of development, the heterogeneity of Chinese business people in France has increased. This is not only reflected in the migration trajectory and social composition of Chinese business people, but also in the generational changes experienced by the ethnic economy and the differentiation by industry of Chinese business people. Before the pandemic, some Chinese entrepreneurs had already made or partially made the transition to "integrating online and offline businesses," "hiring beyond Chinese ethnic networks," and "paying attention to the local country's policy directions," which helped them greatly reduce the negative impacts of the pandemic. Indeed, members of the current generation of young Chinese business people are looking increasingly at French local distribution and logistics. Before the pandemic, these highly skilled Chinese migrants who immigrated to France in the 2000 s had tried to differentiate themselves from the business models of Wenzhou, Chaozhou, and Southeast Asian Chinese merchants that started out by importing and exporting traditional small commodities and managing delicatessen stores. These skilled entrepreneurs (newcomers as well as descendants) looked at the mainstream economic market in France prior to the arrival of the pandemic, hired French employees, and looked for French customers. All of these 
Chinese business economic practices observed over the past two decades have surpassed the traditional "ethnic economy" model (Ma Mung 1994). This is similar to the general characteristics of the global migration economy summarized by Nazareno, Zhou and You (2019).

Since the Covid-19 pandemic, the Chinese entrepreneurs in France who have already achieved or are striving to make business transitions have been relatively lightly affected by the pandemic because they already have comparatively mature digital operations, online orders, mobile apps, and offline delivery or delivery experience. This has been one of the keys to turning crisis into opportunity during the lockdown. Skilled newcomers and young descendants of immigrants play an important role in the digitization of businesses and in the management of multinational e-commerce. The existing Chinese business resources have a trend of combining entrepreneurial model innovation with new technologies. The younger and skilled generation is the main key toward developing that trend.

The second important key to success lies in the diversity of the employees of these Chinese businesses. Our field materials clearly show that it has been much more difficult for Chinese employees to return to work than for employees of other ethnic groups. In many cases, even if the Chinese business owner intends to resume work or continue to operate during the lockdown, the reluctance of Chinese employees to return to work prevents the business from operating. A low self-employment rate, as in the case of $\mathrm{Mr} \mathrm{Wu}$, has enabled continued activity during the pandemic.

Meanwhile, the pandemic has opened up two unprecedented business opportunities. Firstly, "fostering local production." The transnational production and operation chain was severely impacted by the pandemic. This global business model of relying on production and assembly in a low labor market and sale in a high-consumption market is no longer feasible when the global logistics and passenger flow are almost stagnant. Facing the pandemic, France has realized the importance of "local production," especially in the field of medical supplies and equipment. An example of someone who has seized this opportunity is the Chinese businessman Mr Huang Xuesheng, who opened a mask factory in Blanc-Mésnil, a northern suburb of Paris.

"Seeking low-risk sectors" is the second new trend that we identified in the field survey. Many Chinese business people, particularly traditional import and export wholesalers of small commodities and ready-to-wear garments, have begun to actively seek "industries that can continue to operate even if the city is locked down again." The tobacco industry, which was analyzed above, has been identified as one of these "stable industries" and is therefore favored by Chinese business people for investment. 
In general, the Covid-19 pandemic has accelerated the transition of Chinese immigrant entrepreneurship in France. However, the pandemic may not be the direct cause of this business transition; rather, it has created unique conditions which facilitate the transition. Chinese entrepreneurship in France is facing a multi-dimensional reshuffle of industrial structures, business methods, and transformation strategies. Anchoring in the French market, continuing to maintain transnational ties with China, and digitizing and combining the physical industrial chain with online platforms have all become winning strategies for Chinese entrepreneurs in France to reduce the negative impact of the pandemic and successfully adapt their businesses. At the same time, industries that meet basic needs have performed relatively well in the pandemic. This has prompted some Chinese business people to begin to reflect on what constitutes a core industry in the host country.

Previous studies usually focused on the industrial sectors' structuration of Chinese entrepreneurs, the ethnic relationship linking the home country to the host country, and the social integration of descendants over a long period of time. The significance of our research is that, by relying on previous work, it explores the catalytic impact of the Covid-19 pandemic on the Chinese entrepreneurship transition in France, over a short period of time and in a global crisis context. As the consequences of the Covid-19 pandemic will undoubtedly continue to reverberate over time, this innovative empirical research on the French case could provide a model for similar studies on overseas-Chinese entrepreneurs in other national settings in and beyond Europe.

Theoretically, our study suggests that business transitions among Chinese entrepreneurs in France need to be examined beyond the framework of pure economic rationality, taking into consideration "the cross-border interaction

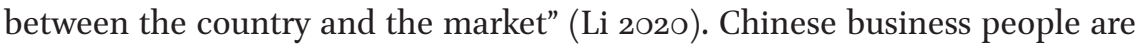
indeed concerned about market trends and policies, as well as the business environments of both the home country and the host country. Cross-cultural, cross-system, cross-thinking, and cross-border activities in the two societies profoundly affect both globalization and changing trends in the post-pandemic era. We might use the theoretical perspective of "simultaneous embeddedness" to observe and understand the current and future major changes in the pandemic and post-pandemic eras.

A few final questions remain. Will the new business models studied here and adopted thus far by Chinese entrepreneurs in France stand the test of time during subsequent phases of the pandemic and afterwards? What are the continuing impacts of the pandemic on the organizational forms and methods of Chinese business people in various industries? What role will the next generation play in business innovation, as they take over family businesses in times 
of pandemic? These questions demand a follow-up to this empirical survey as well as continued investment in fieldwork in the future.

\section{Acknowledgements}

The authors sincerely thank Professor Zhou Min for her suggestions for the revised manuscript, as well as Sophie Haas for the proofreading in English. The authors acknowledge the financial support of the MigraChiCovid funding (France, ANR-2o-COVI-oo46-o1) and the French Collaborative Institute on Migration (ICM) for the open access publication of this article.

\section{References}

Ceccagno, Antonella. 2003. "Le migrazioni dalla Cina verso l'Italia e l'Europa nell'epoca della globalizzazione." (Migrations from China to Italy and Europe in the era of globalization). In Migranti cinesi a Prato. Il distretto tessile multietnico (Chinese migrants in Prato. The multi-ethnic textile district), ed., Ceccagno Antonella, pp. 25-68. Milano-Roma: FrancoAngeli.

Ceccagno, Antonella. 2015. "The Mobile Emplacement: Chinese Migrants in Italian Industrial Districts." Journal of Ethnic and Migration Studies 41(7):1111-1130.

Condliffe, John Bell. 1927. "Problems of the Pacific: Proceedings of the Second Conference of the Institute of Pacific Relations." University of Chicago Press 2:410.

Gaspar, Sofia. 2019. "Chinese Descendants' Professional Pathways: Moving to new Businesses?" Portuguese Journal of Social Sciences 18 (1):91-108.

Guercini, Simone, Matilde Milanesi and Gabi Dei Ottati. 2017. "Paths of Evolution for the Chinese Migrant Entrepreneurship: A Multiple Case Analysis in Italy." Journal of International Entrepreneurship 15: 266-294.

Hassoun, Jean-Pierre and Yinh Phong Tan. 1986. "Les Chinois de Paris: minorité culturelle ou constellation ethnique?" (The Chinese of Paris: Cultural Minority or Ethnic Constellation?). Terrain 7: 34-44.

Le Parisien. 2014. "La moitié des bars-tabacs gérée par la Communauté asiatique." (Half of the Tobacco Bars Managed by the Asian Community). https://www.leparisien .fr/paris-75/la-moitie-des-bars-tabacs-geree-par-la-communaute-asiatique-o8-o2 -2014-3570567.php, accessed on 15 October 2020.

Levitt, Peggy and Nina Glick-Schiller. 2004. "Conceptualizing Simultaneity: A Transnational Social Field Perspective on Society." International Migration Review 38(3):1002-1039. 
Li, Minghun. 2002. "The Network among Organizations and Its Structure of Management in the Domain of Sociology." Sociological Studies 2:30-39.

Li, Minghuan (李明欢). 2019. Ouzhou Huaqiao Huaren Shi 欧洲华侨华人史 (History of Chinese Immigrants in Europe). Guangzhou: Guangzhou: Jinan University Press, $1-2$.

Light, Ivan. 1994. "Beyond the Ethnic Enclave Economy." Social Problems 41(1):601-616. Live, Yusion. 1992. "Les Chinois de Paris depuis le début du siècle. Présence urbaine et activités économiques." (The Chinese in Paris Since the Beginning of the Century. Urban Presence and Economic Activities). Revue Européenne des Migrations Internationales 8(83): 155-173.

Long, Denggao. 1998. "On Overseas Ethnic Chinese Business Networks." Journal of Contemporary Asia-Pacific Studies 4:55-59.

Ma Mung, Emmanuel. 2009. "Le prolétaire, le commerçant et la diaspora." (The Proletarian, the Merchant and the Diaspora). Revue Européenne des Migrations Internationales 25(1): 97-118.

Ma Mung, Emmanuel. 1994. "L'entreprenariat ethnique en France." (Ethnic Entrepreneurship in France). Sociologie du travail 36(2):185-209.

Min, Pyong Gap. 1996. Caught in the Middle: Korean Communities in New York and Los Angeles. University of California Press, Berkeley, CA and Los Angeles, CA.

Nazareno, Jennifer, Min Zhou and Tianlong You. 2019. "Global Dynamics of Immigrant Entrepreneurship: Changing trends, Ethnonational Variations and Reconceptualizations." International Journal of Entrepreneurial Behavior \& Research 25(5): 780-80o.

Nyiri, Pal. 2014. "Training for Transnationalism: Chinese Children in Hungary." Ethnic and Racial Studies 37 (7):1253-1263.

Portes, Alejandro, Luis Eduardo Guarnizo and William J. Haller. 2002. "Transnational Entrepreneurs: an Alternative Form of Immigrant Economic Adaptation." American Sociological Review 67(2): 278-298.

Portes, Alejandro and Patricia Fernandez-Kelly. 2015. The State and the Grassroots: Immigrant Transnational Organizations in Four Continents. Oxford: Berghahn Books.

Spener, David and Frank D. Bean. 1999. "Self-Employment Concentration and Earnings among Mexican Immigrants in the United States." Social Forces 77(3):1021-1047.

Thunø, Mette and Minghuan Li. 2020. "Introduction: New Dynamics of Chinese Migration to Europe." International Migration 58(3): $5^{-21 .}$

Trémon, Anne-Christine. 2012. La Fabrication d'un Quartier Commerçant Chinois à Aubervilliers (The Making of a Chinese Commercial District in Aubervilliers). Paper Presented at LABEX Symposium Transfers 'Les Chinois à Paris: Inscription Spatiale, Morphologie Sociale, Dynamiques Collectives' (The Chinese in Paris: Spatial Inscription, Social Morphology, Collective Dynamics), École Normale Supérieure, Paris, France, 1 June 2012. 
Wang, Chunguang (王春光). 2017. Yimingkongjian de Jiangou:Bali Wenzhouren Genzongyanjiu 移民空间的建构: 巴黎温州人跟踪研究 (Constructing Space: A Longitudinal Study of Immigrants from Wenzhou in Paris). Beijing Shehuikexue Wenxian chubanshe.

Wang, Gungwu (王春武). 2007. “Zhongguo Wenhua Haiwaiguan 中国文化海外观” (Chinese Culture from Outside China), 西安交通大学学报（社会科学版）(Journal of Xi'an Jiaotong University (Social Sciences)) 27(1):1-5.

Wang, Simeng. 2017. "Une mondialisation par le bas. Les daigous à Paris, des agents commerciaux intermédiaires entre producteurs français et consommateurs chinois." (Globalization from Below. Daigous in Paris, Intermediary Sales Agents between French Producers and Chinese Consumers). Cultures et Conflits 108 (4):107-128.

Wang, Simeng. 2019. "Les Mobilités de Français d'Origine Chinoise en Chine: Une Enquête Qualitative (2010-2016)." (The Mobility of French People of Chinese Origin in China: A Qualitative Survey (2010-2016)). In Les migrations des Nords vers les Suds (Migration from the North to the South), eds., Giulia Fabbiano et al., pp. 95-119. Paris: Karthala.

Wang, Simeng. 2020. "Highly Skilled Chinese Immigrants in France. Career Choices, Marriage Behavior and Political Participation." In Chinese immigrants in Europe: Image, Identity and Social Participation, eds., Yue Liu and Simeng Wang, pp. 75-10o. Berlin: Walter de Gruyter GmbH.

You, Tianlong and Min Zhou. 2019. "Simultaneous Embeddedness in Immigrant Entrepreneurship: Global Forces Behind Chinese-Owned Nail Salons in New York City." American Behavioral Scientist 63(2):166-185.

Zhou, Min. 2004. "Revisiting Ethnic Entrepreneurship: Convergencies, Controversies, and Conceptual Advancements." International Migration Review 38(3):1040-1074. 